ANL/OTEC-PS-1

\title{
OTEC Performance Tests of the \\ Union Carbide Flooded-Bundle Evaporator
}

by

L. G. Lewis and N. F. Sather

Ocean Thermal Energy Conversion Program

Argonne National Laboratory

Sponsored by

U. S. Department of Energy

under Contract W-31-109-Eng-38 


\section{DISCLAIMER}

This report was prepared as an account of work sponsored by an agency of the United States Government. Neither the United States Government nor any agency Thereof, nor any of their employees, makes any warranty, express or implied, or assumes any legal liability or responsibility for the accuracy, completeness, or usefulness of any information, apparatus, product, or process disclosed, or represents that its use would not infringe privately owned rights. Reference herein to any specific commercial product, process, or service by trade name, trademark, manufacturer, or otherwise does not necessarily constitute or imply its endorsement, recommendation, or favoring by the United States Government or any agency thereof. The views and opinions of authors expressed herein do not necessarily state or reflect those of the United States Government or any agency thereof. 


\section{DISCLAIMER}

Portions of this document may be illegible in electronic image products. Images are produced from the best available original document. 
The facilities of Argonne National Laboratory are owned by the United States Government. Under the terms of a contract (W-31-109-Eng-38) between the U. S. Department of Energy, Argonne Universities Association and The University of Chicago, the University employs the staff and operates the Laboratory in accordance with policies and programs formulated, approved and reviewed by the Association.

\section{MEMBERS OF ARGONNE UNIVERSITIES ASSOCIATION}

The University of Arizona Carnegie-Mellon University Case Western Reserve University The University of Chicago University of Cincinnati Illinois Institute of Technology University of Illinois Indiana University Iowa State University The University of Iowa
Kansas State University The University of Kansas Loyola University Marquette University Michigan State University The University of Michigan University of Minnesota University of Missouri Northwestern University University of Notre Dame
The Ohio State University

Ohio University

The Pennsylvania State University Purdue University Saint Louis University Southern Illinois University The University of Texas at Austin Washington University Wayne State University The University of Wisconsin

\section{NOTICE}

This report was prepared as an account of work sponsored by the United States Government. Neither the United States nor the United States Department of Energy, nor any of their employees, nor any of their contractors, subcontractors, or their employees, makes any warranty, express or implied, or assumes any legal liability or responsibility for the accuracy, completeness or usefulness of any information, apparatus, product or process disclosed, or represents that its use would not infringe privately-owned rights. Mention of commercial products, their manufacturers, or their suppliers in this publication does not imply or connote approval or disapproval of the product by Argonne National Laboratory or the U. S. Department of Energy.

Printed in the United States of America

Available from

National Technical Information Service

U. S. Department of Commerce

5285 Port Royal Road

Springfield, Virginia 22161

Price: Printed Copy $\$ 4.50$; Microfiche $\$ 3.00$ 
ANL/OTEC-PS-1

ARGONNE NATIONAL LABORATORY

9700 South Cass Avenue

Argonne, Illinois 60439

OTEC PERFORMANCE TESTS OF THE

UNION CARBIDE FLOODED-BUNDLE EVAPORATOR

by

Lloyd G. Lewis and Norman F. Sather

Energy and Environmental Systems Division

December 1978

The Argonne Ocean Thermal Energy Conversion Program

is a joint effort of the

Energy and Environmental Systems Division and Components Technology Division.

sponsored by

U.S. Department of Energy

Division of Central Solar Technology 


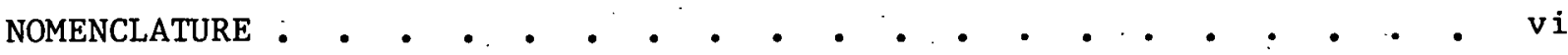
ABSTRACT • • • • • • • • • • • • • • • • • • • • • •

1 INTRODUCTION • • • • • • • • • • • • • . • • • • • • • 11

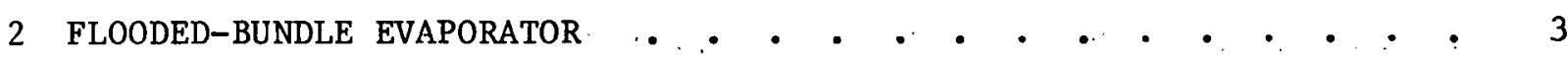

3 HEAT EXCHANGER TEST FACILITY • • • • • • • • • • • • •

3.1 Piping Layout . • • • • • • • • • • • • • • • • 3

3.2 Instrumentation . . • . • • • • • • . • • . . . 7

3.3 Data Handling System • • • • • • • • • • • • • • 8

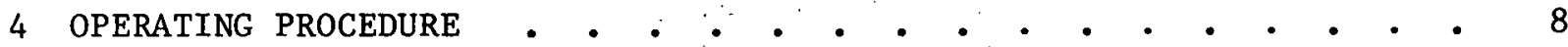

5 METHODS OF CALCULATION

5.1 Equations for the Overall Heat Transfer Coefficient • • • . 10

5.2 Error Analysis • • • • • • • • • • • • • • • • 12

6 TEST RESULTS • • • • • • • • • • • • • • • • • • • 15

6.1 Initial Runs: Deactivation and Reactivation of the
High Flux Surface . . . . . . . . . . . . . . . 15

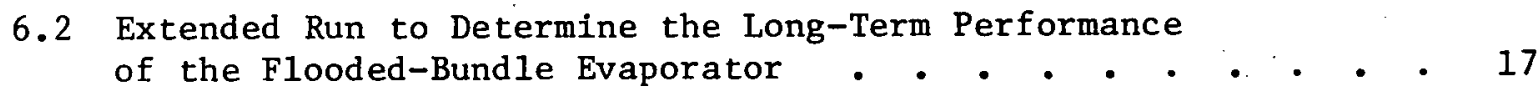

6.2.1 Steady-State Value of $\mathrm{U}_{\mathrm{o}}$ for Design
Operating Conditions . . . . . . . . . . . . . 18

6.2.2 Individual Heat Transfer Coefficients . • . • . . 18

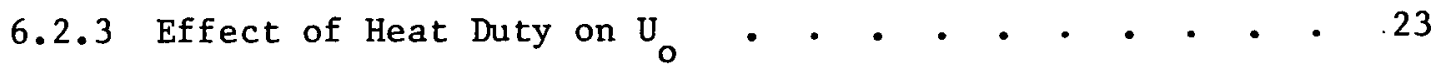

6.2.4 Effect of Temperature of the
Liquid Ammonia Feed to the Evaporator . . . . . . 23

6.2.5 Water-Side Pressure Drop . . . . . . . . . . 24

6.2 .6 Vapor Quality . • . • • • • • • • • • • $~ 24$

7 SUMMARY AND CONCLUSIONS • • • • • • • • • • • • • • • 25

REFERENCES • • • • • • • • • • • • • • • • • • • • 27

ACKNOWLEDGMENTS $\quad$ • • • • • • • • • • • • • • • • • • • • • 


\section{:LIST OF FIGURES}

1 Union Carbide Flooded-Bundle Evaporator • • • . • • • • . . 4

2 OTEC Heat Exchanger Test Facility • • • • • • • • • • • $~ 6$

3 . Sample Data Printout • • • • • • • • • • • • • • • •

4 Extended Run Results • • • • • • • • • • • • • • • • 19

5 Wilson Plot • • • • • • • • • • • • • • • • • • • • •

6 Variation of Water-Side Coefficient with Water Flow Rate . . . . 23

\section{LIST OF TABLES}

1 Nominal Design Parameters for the Flooded-Bundle Evaporator * . . 5

2 Instruments and Measurement Accuracy . . • . . . . . . . . 8

3 Values of $\mathrm{U}_{0}$ as a Function of Flow Rate . . . . . . . . . . . 21

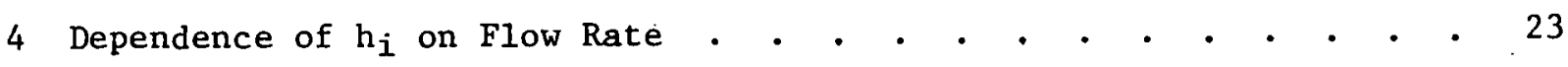

5 Water-Side Pressure Drop as a Function of Flow Rate • • . • • • 24 
$A_{i}$ Inside surface area of heat exchanger tubes, $f t^{2}$

A $1 \mathrm{~m}$

A

c

$c_{p e}^{\prime}$

$\mathrm{C}_{\mathrm{ph}}$

$\Delta \mathrm{H}_{\mathrm{e}}^{\prime}$

$h_{f i}$

ho

$h_{i}$

h

$k$

$\mathrm{m}_{\mathrm{e}}$

$\mathrm{m}_{\mathrm{h}}$

$\mathrm{m}_{\ell}^{\prime}$

$\Delta \mathrm{p}_{\mathrm{e}}$

$\Delta \mathrm{p}_{\mathrm{pw}}$

$\mathrm{q}_{\mathrm{e}} \mathrm{I}$

$q_{e 2}$

$q_{e}^{\prime}$

$r_{i}$

ro

$\Delta \mathrm{r}$

$\mathrm{T}_{\mathrm{a}}$

Tei

$\mathrm{T}$ eo

$T^{\prime}$

$\Delta \mathrm{T}$.

$\Delta \mathrm{T}_{\mathrm{e}}^{\prime}$

$\Delta \mathrm{T}_{\mathrm{h}}$

$\Delta \mathrm{T}_{1 \mathrm{me}}$

$\mathrm{U}_{\mathrm{o}}$

$w_{e}$ Water flow rate through evaporator, gpm

Outside surface area of heat exchanger tubes, $\mathrm{ft}^{2}$

Heat capacity of water in evaporator, $\mathrm{Btu} / 1 \mathrm{~b} \cdot{ }^{\circ} \mathrm{F}$

Heal capacily of waler In healer, $B t u / 1 b \cdot{ }^{n} \mathrm{~F}$

Conductivity of tube wall material, Btu/hr $\cdot \mathrm{ft} \cdot{ }^{\circ} \mathrm{F}$

Mass flow rate of water through heater, $1 \mathrm{~b} / \mathrm{min}$

Mass flow rate of ammonia around loop, 1b/min

Water-side pressure drop through evaporator, psi

Pressure increase across warm water pump, psi from water temperature change, $\mathrm{Btu} / \mathrm{hr}$ from warm-water loop energy balance, Btu/hr the evaporator, Btu/hr

Inside radius of heat exchanger tubes, ft

Outside radius of heat exchanger tubes, ft

Wall thickness $\left(r_{0}-r_{i}\right)$, ft

Ambient temperature, ${ }^{\circ} \mathrm{F}$

Temperature of warm water enteṛing evaporator, ${ }^{\circ} \mathrm{F}$

Temperature of warm water leaving evaporator, ${ }^{\circ} \mathrm{F}$

Log-mean temperature difference in evaporator, ${ }^{\circ} \mathrm{F}$ $\mathrm{Btu} / \mathrm{hr} \cdot \mathrm{ft}^{2} \cdot{ }^{\circ} \mathrm{F}$

Log-mean area of heat exchanger tubes, $\mathrm{ft}^{2}$

Heat capacity of liquid ammonia entering evaporator, $\mathrm{Btu} / 1 \mathrm{~b} \cdot{ }^{\circ} \mathrm{F}$

Heat of vaporization of ammonia in evaporator, Btu/1b

Fouling coefficient for inside of tubes, $\mathrm{Btu} / \mathrm{hr} \cdot \mathrm{ft}^{2} \cdot{ }^{\circ} \mathrm{F}$

Fouling coefficient for outside of tubes, Btu/hr$\cdot f t^{2} \cdot{ }^{\circ} \mathrm{F}$

Heat transfer coefficient for inside surface (water), Btu/hr $\cdot \mathrm{ft}^{2} \cdot{ }^{\circ} \mathrm{F}$

Heat transfer coefficient for outside surface (ammonia), Btu/hr.ft ${ }^{2} \cdot{ }^{\circ} \mathrm{F}$

Mass flow rate of water through evaporator, $1 \mathrm{~b} / \mathrm{min}$

Rate of heat transferred from warm water in evaporator calculated

Rate of heat transferred from warm water in evaporator calculated

Rate of heat transferred to ammonia stream during passage through

Temperature of ammonia vapor leaving evaporator, ${ }^{\circ} \mathrm{F}$

Water-side temperature drop through evaporator, ${ }^{\circ} \mathrm{F}$

Temperature increase of liquid ammonia entering evaporator, ${ }^{\circ} \mathrm{F}$

Water-side temperature increase through heater, ${ }^{\circ} \mathrm{F}$

Overall heat transfer coefficient based on outside tube surface area, 


\section{OTEC PERFORMANCE TESTS OF THE \\ UNION CARBIDE FLOODED-BUNDLE EVAPORATOR}

by

Lloyd G. Lewis and Norman F. Sather

ABSTRACT

Results of performance tests conducted on a Ünion Carbide flooded-bundle evaporator with High Flux titanium tubes are reported. At design operating conditions (a heat duty of 3.2 million $B t u / h r$, an inlet water temperature of $80^{\circ} \mathrm{F}$, and a water flow rate of $3200 \mathrm{gpm}$ ) the steady-state value of the overall heat transfer coefficient $\left(U_{0}\right)$ was found to be $785 \mathrm{Btu} / \mathrm{hr} \cdot \mathrm{ft}^{2} \cdot{ }^{\circ} \mathrm{F}$, and the ammonia-side and water-side heat transfer coefficients were 4800 and 1400 $\mathrm{Btu} / \mathrm{hr} \cdot \mathrm{ft}^{2} \cdot{ }^{\circ} \mathrm{F}$, respectively. The water-side pressure drop was 2.7 psi. Variations in heat duty $( \pm 25 \%)$ and liquid ammonia feed temperature (over the range of $48-64^{\circ} \mathrm{F}$ ) did not affect thermal performance significantly. On the other hand, $\mathrm{U}_{\mathrm{O}}$ was reduced appreciably by operational shutdowns during which nonboiling ammonia remained in contact with the High Flux surface for periods of 30 minutes or more. During a one-hour shutdown the value of $\mathrm{U}_{\mathrm{O}}$ decreased to $690 \mathrm{Btu} / \mathrm{hr} \cdot \mathrm{ft}^{2} \cdot{ }^{\circ} \mathrm{F}$, and values as low as $600 \mathrm{Btu} / \mathrm{hr} \cdot \mathrm{ft}^{2} \cdot{ }^{\circ} \mathrm{F}$ were reached for longer shutdowns. Such contact appears to deactivate some of the nucleate boiling sites, thus reducing the heat transfer coefficient. Although operation of the evaporator under boiling conditions reverses this effect, reactivation takes place much more slowly than deactivation. Procedures for avoiding this problem in the operation of the High Flux floodedbundle evaporator are given.

\section{INTRODUCTION}

Energy stored in the warm surface waters of the tropical oceans can be converted to electrical energy in a suitably designed power plant. Although Ocean Thermal Energy Conversion (OTEC) plants can utilize the warm ocean water directly as the working fluid, the primary emphasis in the current federal development program is on closed-cycle plants that use ammonia or some other refrigerant in a Rankine power cycle. In such a plant the warm water is pumped through a heat exchanger where thermal energy of the water is transferred to the ammonia, causing it to vaporize. 
The vaporized ammonia, under pressure, flows from the exchanger through a turbine-generator that converts the pressure energy into electrical energy. The vapor then flows to a second heat exchanger where the ammonia is condensed at low pressure. Here the heat of condensation is transferred to a cold water stream that is pumped up to the condenser from the ocean depths. Finally, the liquid ammonia is pumped back to the evaporator to complete the cycle.

Since the temperature difference between the warm and cold ocean water is at most $35-40^{\circ} \mathrm{F}$, the net energy conversion efficiency of the plant is Low $(\simeq 3 \%)$ and the amount of thermal energy that can be obtained from a pound of water is small (corresponding to $2-4^{\circ} \mathrm{F}$ sensible heat). Consequently, the heat exchangers must handle very large heat duties and water flows, on the order of $100 \mathrm{million} B t u / h r$ and 100 thousand gpm per megawatt of generating capacity. This means that the heat exchangers will be much larger and more costly than those used in conventional coal and nuclear power plants.

However, improvements in the performance of the evaporator and condenser can significantly reduce both capital and operating costs. The performance of the exchangers is characterized by two quantities, the overall heat transfer coefficient and the water-side and ammonia-side pressure drops. The latter are important because the parasitic power required for pumping is proportional to them. Clearly, cost trade-offs between pumping power and heat-transfer performance are possible. For example, increasing the water velocity through the exchanger will improve the heat transfer coefficient and thereby reduce the amortized equipment cost, but at the expense of a larger pumping power cost. Water-side and ammonia-side heat transfer enhancement techniques offer similar trade-off possibilities and, hence, opportunities for maximizing the overall cost-effectiveness of the heat exchangers. The most cost-effective design would take into account costs of biofouling control, pumping, and the amortized cost of materials and fabrication.

The purpose of this report is to present and discuss the results of performance tests on an enhanced-tube flooded-bundle evaporator designed by Union Carbide Corporation. The tests were run at the newly constructed 
OTEC heat exchanger test facility at Argonne. This evaporator is the first of a series of high-performance heat exchangers that will be tested. Reports on other shell-and-tube evaporators and condensers, as well as on several shell-less types of heat exchangers, will be issued as performance tests are completed. All of the heat exchangers involved are sized to handle 3.2 million $\mathrm{Btu} / \mathrm{hr}$, corresponding to $1 / 40$ MWe capacity. Consequently, through these tests it should be possible to determine whether the performance anticipated on the basis of single-tube experiments can be achieved in large tube-bundle configurations. Such information is necessary before full-size commercial OTEC plants can be designed.

\section{FLOODED-BUNDLE EVAPORATOR}

The Linde Division of Union Carbide Corporation supplied a floodedbundle evaporator for testing at Argonne. The evaporator, a horizontal shell-and-tube exchanger, has titanium tubes with the Linde High Flux coating on their outer surfaces that are in contact with the vaporizing ammonia. This surface coating is a thin layer of porous metal that promotes nucleate boiling. The water.side has three passes with the warm water feed at the bottom; as shown in Fig. 1. Table 1 gives the nominal design/operating parameters for this exchanger.

\section{3 :HEAT EXCHANGER TEST FACILITY}

\subsection{PIPING LAYOUT}

A piping schematic of the OTEC heat exchanger test facility at Argonne is shown in Fig. 2. The facility consists of a warm water loop, a test evaporator, an ammonia loop, a test condenser, and a cold water loop.

The nominal heat duty of the warm water loop is 3.2 million Btu/hr; however, the heater and steam supply line are sized to handle up to 6 million $\mathrm{Btu} / \mathrm{hr}$. The heater can be set for a constant heat duty over the range of 0.5-6 million $\mathrm{Btu} / \mathrm{hr}$. The warm water flow rate is a nominal $3200 \mathrm{gpm}$, but the pipe and pump are sized for flows up to $8000 \mathrm{gpm}$. This large range of flows improves the accuracy of calculation of the individual water-side and ammonia-side heat transfer coefficients. An important feature of the 


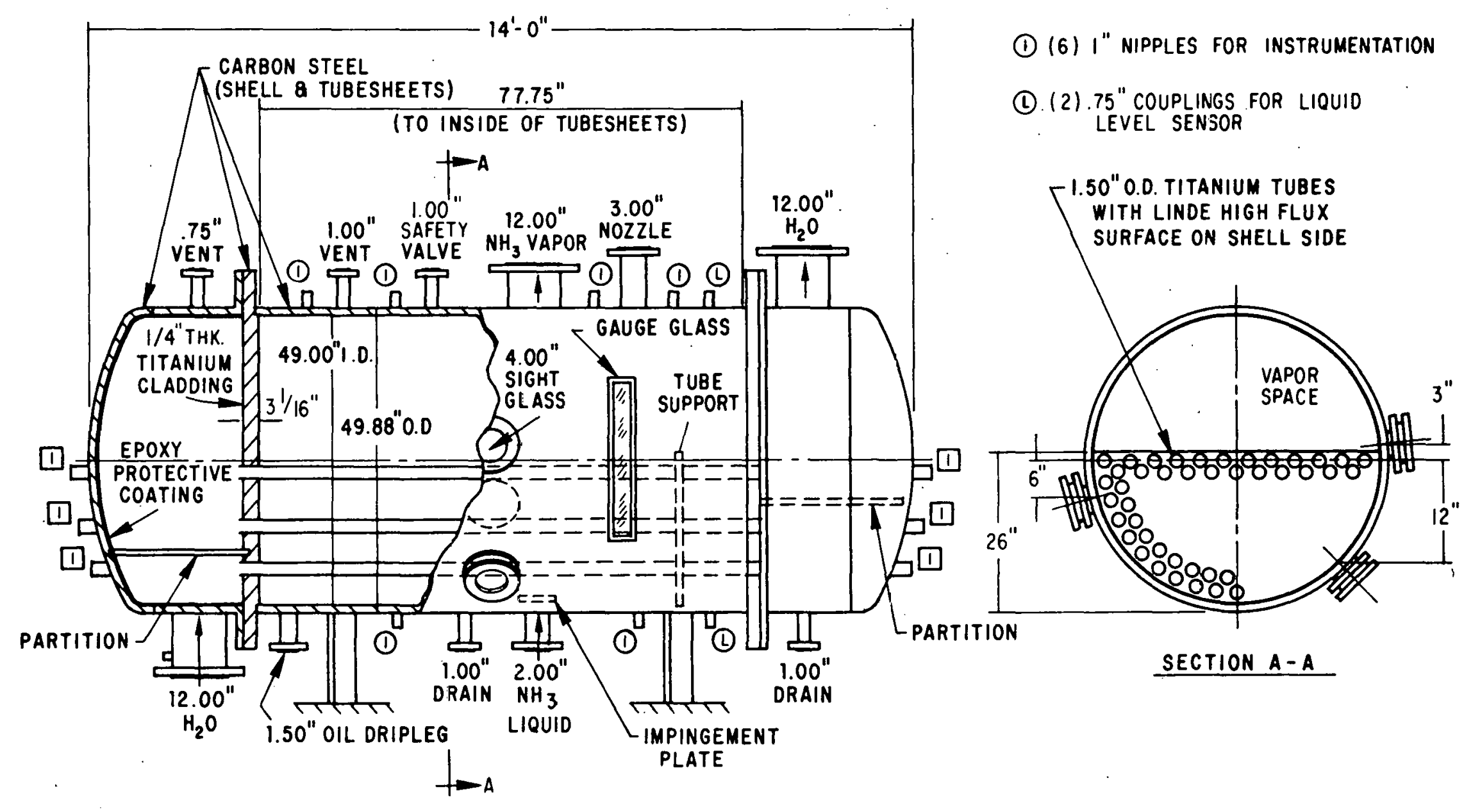

Fig. 1. Union Carbide Flooded-Bundle Evaporator 
Table 1. Nominal Design Parameters for the Flooded-Bundle Evaporator

\begin{tabular}{|c|c|}
\hline Parameter & Value \\
\hline $\begin{array}{l}\text { Heat duty } \\
\text { Ammonia boiling temperature } \\
\text { Water inlet temperature } \\
\text { Water out let temperature } \\
\text { Number of tubes }\end{array}$ & $\begin{array}{l}3.2 \mathrm{mil} \\
72^{\circ} \mathrm{F} \\
80^{\circ} \mathrm{F} \\
78^{\circ} \mathrm{F} \\
279^{\circ}\end{array}$ \\
\hline $\begin{array}{l}\text { High Flux coated tube length } \\
\text { Tube outside diameter (excluding coating) } \\
\text { Tube inside diameter } \\
\text { Effective outside heat transfer area } \\
\text { Mean water velocity in tubes }\end{array}$ & $\begin{array}{l}75 \mathrm{in} . \\
1.50 \mathrm{in} . \\
1.43 \mathrm{in} . \\
685 \mathrm{ft}^{2} \\
6.8 \mathrm{ft} / \mathrm{sec}\end{array}$ \\
\hline $\begin{array}{l}\text { Overal1 water-side pressure drop } \\
\text { Shell inside diameter } \\
\text { Shell-side design pressure } \\
\text { Tube-side design pressure } \\
\text { "Clean" overall heat transfer coefficient" }\end{array}$ & $\begin{array}{l}2.75 \mathrm{psi} \\
49 \mathrm{in} . \\
215 \mathrm{psig} \\
100 \mathrm{psig} \\
768 \mathrm{Btu} / \mathrm{hr} \cdot \mathrm{ft}^{2} \cdot{ }^{\circ} \mathrm{F}\end{array}$ \\
\hline \multicolumn{2}{|c|}{$\begin{array}{l}\text { Source: Caikk, A.M., et al., Fluid Dynamics and Heat Transfer } \\
\text { Studies of OTEC Heat Exchangers, Linde Division, Union Carbide } \\
\text { Corporation, P.O. Box } 44 \text {, Tonawanda, N.Y. 14150. } \\
\mathrm{a}_{\text {Based on actual coated tube length of } 75 \mathrm{in} \text {; }} \text { the total tube } \\
\text { length between the tube sheets is } 2.75 \text { in. longer. } \\
\mathrm{b}_{\text {Based on outside tube surface area. Assumes no tube-side or }} \\
\text { shell-side fouling. }\end{array}$} \\
\hline
\end{tabular}

flow loop is a bypass around the warm water heater. Typically, about $10 \%$ of the water flows through the heater and $90 \%$ flows through the bypass line. The temperature of the water passing through the heater is raised by about $20^{\circ} \mathrm{F}$; when the heated water is mixed with the water from the bypass line, the desired water temperature is achieved. This arrangement greatly improves the accuracy of measurement of the heat input from the steam heater. Static mixers are used to eliminate radial temperature variations at locations where measurements of bulk mean temperatures are needed.

The ammonia loop is provided with a demister that removes entrained liquid droplets from the vapor stream and returns them to the evaporator. The demister contains a 6-in.-thick pad woven from polypropylene filaments. The ammonia droplets are caught on the pad and returned to the evaporator as a liquid stream from the bottom of the demister vessel. The manufacturer's rating indicates that all but submicron-sized particles are caught at the 


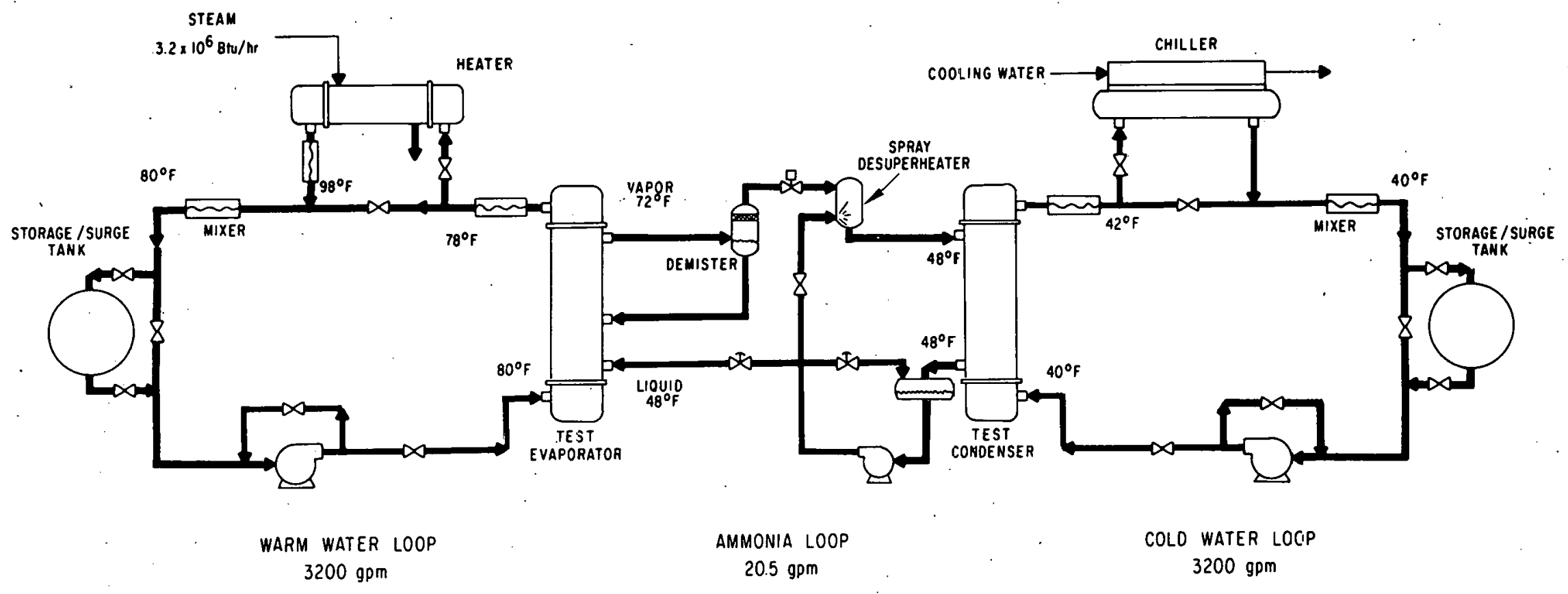

Fig. 2. OTEC Heat Exchanger Test Facility 
vapor velocities of the tests. A turbine flowmeter rated at 0.5-5 $\mathrm{gpm}$ is installed in the liquid line from the demister to measure the flow rate of the returned 1iquid. For very high quality vapor ( $>99 \%$ ) an alternate means of measurement must be used. This consists of a shutoff valve located in the vertical return pipe from the demister and a differential pressure cell to measure the rate of accumulation of liquid in the line. The pressure cell is capable of detecting the accumulation of less than 1 in. ${ }^{3}$ of liquid in the running time of several hours. The ammonia loop also contains an expansion valve and a spray desuperheater for adjusting the pressure and quality of the vapor supplied to the test condenser. The ammonla 11quid from the condenser is returned to the evaporator by a pump that can handle flows corresponding to heat duties up to 6 million Btu/hr;

The cold water loop contains a chiller capable of removing up to 6.4 million $\mathrm{Btu} / \mathrm{hr}$ from the recirculating cold water flow. Condenser inlet water temperatures as low as $40^{\circ} \mathrm{F}$ are possible over most of the range of heat duties. However, at duties above 5 million Btu/hr, a $40^{\circ} \mathrm{F}$ cold water temperature cannot be attained because the required refrigerant temperature is below the capability of the chiller. The nominal cold water flow rate is $3200 \mathrm{gpm}$, but the pump and pipe are sized to handle as much as $8000 \mathrm{gpm}$ if necessary. The chiller is rated at $4000 \mathrm{gpm}$ maximum; the bypass around the chiller can be used to obtain the higher flows needed for determining the film heat transfer coefficients. Static mixers are also used in the cold water loop to facilitate measurement of bulk mean temperatures.

\subsection{INSTRUMENTATION}

Pressures, temperatures and flow rates are measured in each of the three test facility loops. The instruments used were chosen on the basis of measurement accuracy and compatibility with the computer data handling system. The original accuracy goals for measurements characterizing overall performance of the heat exchangers were $\pm 3 \%$ for the overall heat transfer coefficient and $\pm 5 \%$ for the water-side pressure drop. In all instances these goals were met or surpassed during testing. Table 2 lists the more important instruments used and the accuracy of measurement obtained routinely during test operations. 
Table 2. Instruments and Measurement Accuracy

\begin{tabular}{|c|c|c|}
\hline Quantity measured & Instrument & $\begin{array}{l}\text { Accuracy of } \\
\text { measurement }\end{array}$ \\
\hline \multicolumn{3}{|l|}{ Temperature of: } \\
\hline $\begin{array}{l}\text { Water into and out of evaporator } \\
\text { Ammonia vapor in evaporator and } \\
\text { after expansion valve }\end{array}$ & $\begin{array}{l}\text { Quartz crystal } \\
\text { thermomeler }\end{array}$ & $\pm 0.010^{\circ} \mathrm{F}$ \\
\hline $\begin{array}{l}\text { Water into and out of heater } \\
\text { Liquid ammonia feed to evaporator }\end{array}$ & $\begin{array}{l}\text { Copper-constantan } \\
\text { thermocouple }\end{array}$ & $\pm 0.1^{\circ} \mathrm{F}$ \\
\hline \multicolumn{3}{|l|}{ Pressure of: } \\
\hline $\begin{array}{l}\text { Ammonia vapor in evaporator and } \\
\text { after expansion valve }\end{array}$ & $\begin{array}{l}\text { Quartz crystal } \\
\text { transducer }\end{array}$ & \pm 0.005 psia \\
\hline \multicolumn{3}{|l|}{ Pressure difference of: } \\
\hline $\begin{array}{l}\text { Water into and out of evaporator } \\
\text { Water into and out of pump } \\
\text { Static head of liquid ammonia in } \\
\text { evaporator (1iquid level) }\end{array}$ & $\begin{array}{l}\text { Straln gauge } \\
\text { transducer }\end{array}$ & $\begin{array}{l} \pm 0.5 \% \\
\text { of reading }\end{array}$ \\
\hline \multicolumn{3}{|l|}{ Flow rate of: } \\
\hline $\begin{array}{l}\text { Water through evaporator } \\
\text { Water through heater }\end{array}$ & Turbine meter & $\begin{array}{l} \pm 0.15 \% \\
\text { of reading }\end{array}$ \\
\hline $\begin{array}{l}\text { Liquid ammonia feed to evaporator } \\
\text { Liquid ammonia from demister }\end{array}$ & Turbine meter & $\begin{array}{l} \pm 0.5 \% \\
\text { of reading }\end{array}$ \\
\hline
\end{tabular}

\subsection{DATA HANDLING SYSTEM}

The test facility has a computer-based data system that can, on command, read the sources of data, apply calibration and correction factors to these data, compute heat balances and overall heat transfer coefficients, and produce hard-copy records of all measured and calculated quantities. Fig. 3 shows a typical hard-copy output of the data calculated for a particular test run. Most of the entries in Fig. 3 are self-explanatory; those that are not will be discussed in Sec. 5 .

\section{OPERATING PROCEDURE}

The Union Carbide flooded-bundle evaporator was mounted on the test stand in the condition in which it was received, without cleaning, since the heat transfer surfaces had been maintained in a protected, clean condition during shipment. Cleanliness was also maintained during installation. How- 


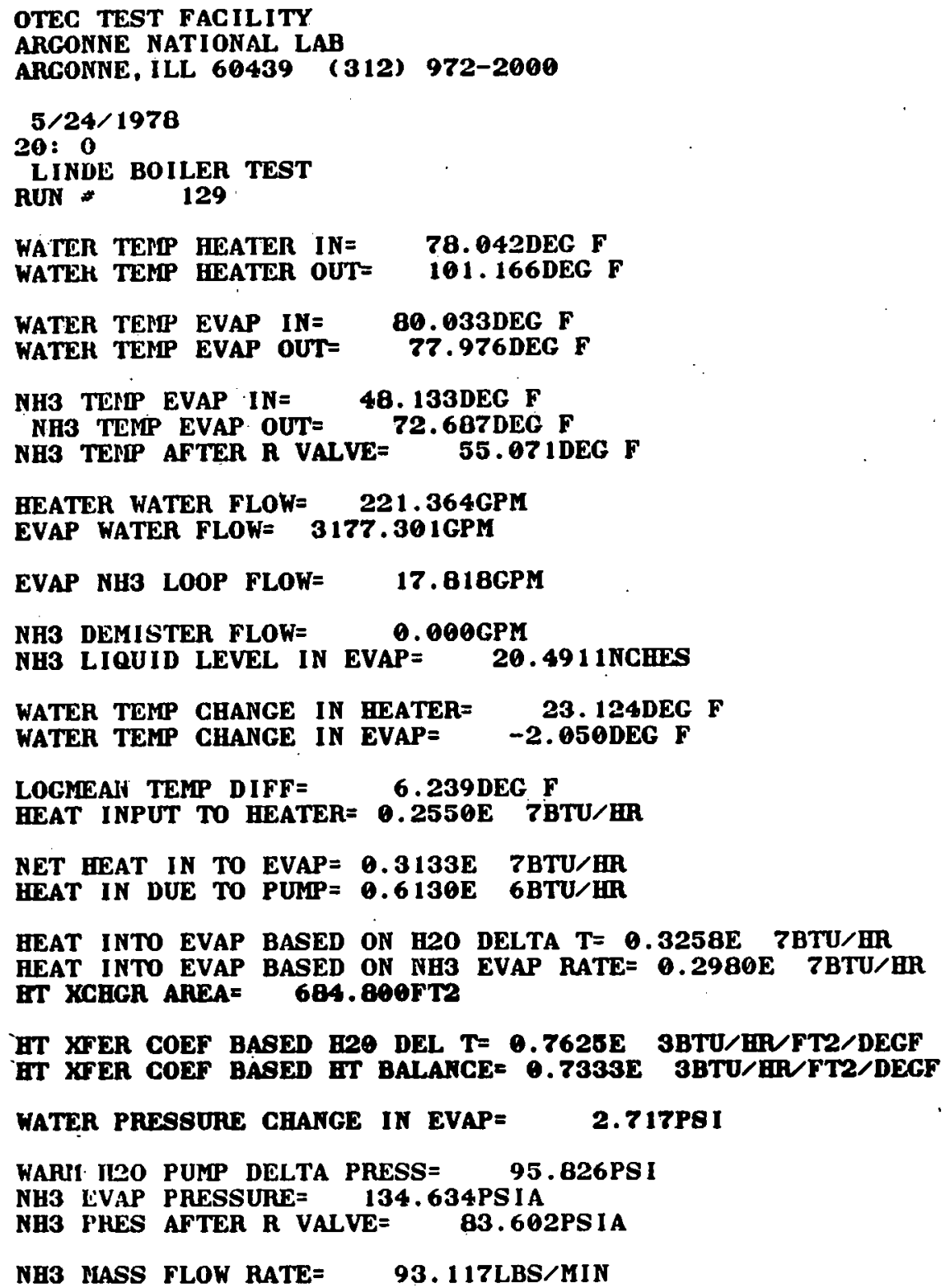

Fig. 3. Sample Data Printout

ever, some rust and other granular material was present on the inside of the shell, on the viewing windows, and on the porous tube coating. After all piping and instrumentation connections were made, the system was pressurechecked for leaks.

As far as the test facility itself is concerned, all piping, valves, and vessels of the ammonia system (excluding the test heat exchangers) were 
cleaned with hot caustic to remove grease. Acid washing (pickling) was then performed to remove rust, mill scale, and particles of iron left from the welding performed during fabrication. The surfaces were then passivated, flushed with water, and put under a nitrogen blanket. Prior to the start of testing, the ammonia system was evacuated to remove noncondensables and water from the shell side of the evaporator, from the ammonia side of the condenser, and from the ammonia piping. The system was then filled with ammonia.

The warm water loop was cleaned and passivated by the same procedure used for the ammonia system. The loop was then filled with potable water that had first been through two water-softening treatments. A corrosion and fouling inhibitor ( Nalco 8330) was then added to the water to produce a concentration of 3 oz per gallon.

At the beginning of an operating period, the water and ammonia pumps were started, the steam flow to the heater was turned on, and the chiller was started. Flows and temperatures were adjusted to the desired values and, when steady operation had been attained (usually 40-60 minutes after start-up), the data for the run were taken. Several sets of data were obtained at intervals of 15-30 minutes before changing to a new set of operating conditions. The procedure was then repeated.

At the end of the day the 1iquid ammonia was pumped from the system back to the storage tank. During those times that the system was not operating, such as nights and weekends, ammonia vapor was left under pressure in the ammonia loop to prevent air from leaking into the system. At the beginning of the next operating period, liquid ammonia was pumped back into the evaporator and condenser. The pumps, heater, and chiller were started, and data taking was resumed.

\section{METHODS OF CALCULATION}

\subsection{EQUATIONS FOR THE OVERALL HEAT TRANSFER COEFFICIENT}

It is evident from the foregoing discussion of the measurements made during testing that there are three Independent ways of determining the heat 
duty of the evaporator. These are:

1. The rate at which heat is given up by the warm water as it passes through the evaporator. This can be expressed as follows: *

$$
q_{e l}=60 m_{e} c_{p e} \Delta T_{e}+1.484 w e^{\Delta p_{e}}
$$

where the firet tcrm is the senslule hear lost by the water as it flows through the evaporator, and the second is the frictional heat added. As might be expected, the frictional heat addition is quite small, amounting to less than $0.5 \%$ of $q_{e}$ for all runs with the flooded-bundle evaporator.

2. The rate at which heat is added to the warm water as it flows around the loop from the evaporator discharge nozzie back to the evaporatior inlet. This includes the net effect of the heat added by the steam heater and the pump, and lost from the pipe surfaces by convection. Thus:

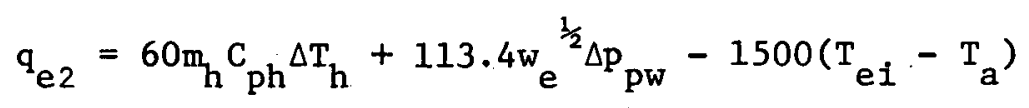

The second term on the right side of Eq. 2 represents the rate of energy addition to the water by the pump. This term was obtained by making an empirical curve fit to the manufacturer's efficiency data for this pump for flows between 2400 and $4000 \mathrm{gpm}$.

3. The rate at which heat is added to the ammonia as it passes through the evaporator. This includes both the sensible heat gain of the subcooled liquid as it is warmed to the saturation temperature and the latent heat of vaporization added as the ammonia boils. In equation form, this is:

$$
q_{e}^{\prime}=60 m_{\ell}^{\prime}\left(\Delta H_{e}^{\prime}+C_{p e}^{\prime} \Delta T_{e}^{\prime}\right)
$$

During steady-state operation these three values of the evaporator heat duty $\left(q_{e l}, q_{e 2}\right.$, and $\left.q_{e}^{\prime}\right)$ must be equal; consequently, the accuracy of the measurements can be checked by comparing the values obtained from the

* See list of nomenclature for explanation of symbols. 
experimental data. However, it must be emphasized that the three methods are not equally accurate. Therefore, it cannot be assumed that the difference between the results obtained by any two methods represents the error in either method.

Once a value of the evaporator heat duty, $q_{e}$, is obtained, the overall heat transfer coefficient, $U_{o}$, is calculated from the conventional definition:

$$
\mathrm{U}_{\mathrm{o}}=\frac{\mathrm{q}_{\mathrm{e}}}{\mathrm{A}_{\mathrm{o}} \Delta \mathrm{T} \text { 1me }}
$$

where:

$$
\begin{aligned}
& \mathrm{A}_{\mathrm{o}}=\text { the outside surface area of the tubes, and } \\
& \Delta \mathrm{T}_{1 \mathrm{me}}= \text { the log-mean temperature difference between the water } \\
& \text { and ammonia streams. }
\end{aligned}
$$

$\Delta \mathrm{T}_{1 \mathrm{me}}$ can be expressed in equation form as follows:

$$
\Delta \mathrm{T}_{1 \mathrm{me}}=\frac{\Delta \mathrm{T}_{\mathrm{e}}}{\ln \left[\frac{\mathrm{T}_{\text {ei }}-\mathrm{T}_{\text {eo }}^{\prime}}{\mathrm{T}_{\text {eo }}-\mathrm{T}_{\text {eo }}^{\prime}}\right]}
$$

\subsection{ERROR ANALYSIS}

Before the test data on the flooded-bundle evaporator and the resulting heat transfer coefficients calculated from these equations are presented, a brief discussion of the magnitude of the expected uncertainties in $q_{e}$ and $U_{0}$ that result from inaccuracles in the directly measured quantities is perhaps in order. We can determine these uncertainties by analyzing the propagation of the potential measurement errors (discussed in Sec. 3.2) in calculations with Eqs. 1 to 5 above.

The first method of calculating the heat duty (Eq. 1) involves the $\Delta \mathrm{T}_{\mathrm{e}}$ measurement (with a measurement accuracy of $\pm 0.3 \%$ ) and the flow rate measurement ( $\pm 0.15 \%$ accuracy); the expected accuracy in $\mathrm{q}_{e l}$ is therefore $\pm 0.4 \%$ (note that the error contribution of the frictional term is negligible). This is in agreement with the observed scatter in the values of $q_{e}$ calculated from successive measurements during steady operation at fixed run conditions; the data generally fell wel1 within a band that was $1 \%$ wide. 
The uncertainty. in $U_{O}$ is determined by examining the following equation, which results from combining Eqs. 1, 4, and 5 and neglecting the frictional heat addition:

$$
\mathrm{U}_{\mathrm{o}} \simeq \frac{60 \mathrm{~m}_{\mathrm{e}} \mathrm{C}_{\mathrm{pe}}}{\mathrm{A}_{\mathrm{o}}} \ln \left[\frac{\mathrm{T}_{\mathrm{ei}}-\mathrm{T}_{\text {eo }}^{\prime}}{\mathrm{T}_{\text {eo }}-\mathrm{T}_{\text {eo }}^{\prime}}\right]
$$

The uncertainty in $\mathrm{U}_{0}$ is due in part to inaccuracies in measurements of $\mathrm{T}_{e}$ and $\mathrm{T}_{\text {eo }}$ obcalned with quartz crystal thermometers. These inaccuracies arise from the inherent precision limits of the thermometers and from small errors introduced during calibration. The standard calibration procedure is to place both measuring probes in a slush of ice made from distilled water. The difference in the two temperatures is first adjusted to read $0^{\circ}$, and then each of the probes is adjusted separately to read the ice water temperature. This is required, since the electronic circuits are switched when selecting any one of the three outputs, $\mathrm{T}_{e i}, \mathrm{~T}_{e o}$, or $\mathrm{T}_{e i}-\mathrm{T}_{\mathrm{eo}}$. When the instrument was calibrated in this way, the two temperature readings were found to differ by $0.054^{\circ} \mathrm{F}$ at $78^{\circ} \mathrm{F}$. This resulted from the instrument having only one slope adjustment that was set at the average value of the two probes and then used for both probes. It was found that considerable improvement in the accuracy of the measurement of $\mathrm{T}_{e i}-\mathrm{T}_{e}$ could be made by adjusting the instrument at the operating temperature of $80^{\circ} \mathrm{F}$. After the standard calibration was completed, simultaneous readings of the warm water temperature at the same point in the loop were made with the two probes. Both were then adjusted to indicate the average of the original readings, and $\Delta \mathrm{T}$ was adjusted to read zero. Values for $\mathrm{T}_{e}, \mathrm{~T}_{\mathrm{eo}}$, and $\Delta \mathrm{T}_{\mathrm{e}}$ are given in $\mathrm{Fig} .3$; "water temp evap in" is $\mathrm{T}_{e i}$, "water temp evap out" is $\mathrm{T}_{e o}$, and "water temp change in evap" is $\Delta \mathrm{T}_{e}$. It can be noted that $\mathrm{T}_{e i}-\mathrm{T}_{\text {eo }}$ differs from $\Delta \mathrm{T}_{\mathrm{e}}$ by $0.007^{\circ} \mathrm{F}$. This is because the three readings are independent measurements. We will use $\pm 0.010^{\circ} \mathrm{F}$ as the maximum measurement error in readings of $\Delta \mathrm{T}_{e}, \mathrm{~T}_{\mathrm{ei}}, \mathrm{T}_{\mathrm{eo}}$, and $\mathrm{T}_{\mathrm{e} o}^{\prime}$. By applying this measurement error to $\mathrm{Eq} \cdot 6$, the uncertainty in $\mathrm{U}_{\mathrm{O}}$ can now be calculated. A $0.010^{\circ} \mathrm{F}$ error in $\mathrm{T}_{\text {éo }}^{\prime}$ causes a relatively small $( \pm 0.145 \%)$ error in the natural logarithm factor. However, errors of $0.010^{\circ} \mathrm{F}$ in $\mathrm{T}_{e} i$ and $\mathrm{T}_{e o}$ cause errors in this factor of $\pm 0.435 \%$ and $\pm 0.580 \%$, respectively, at our operating conditions. Hence, the estimated uncertainty in $U_{0}$ is the combined effect of the flowmeter uncertainty $( \pm 0.15 \%)$ and the three sources of uncertainty because of posisible errors in 
$\mathrm{T}_{\mathrm{ei}}, \mathrm{T}_{\mathrm{eo}}$, and $\mathrm{T}_{\text {éo }}^{\prime}$. Since these error components are independent of one another, the total probable error is $\pm\left(0.15^{2}+0.435^{2}+0.580^{2}+0.145^{2}\right)^{\frac{1}{2}}$ $= \pm 0.75 \%$.

The second method of calculating the heat duty $\left(\mathrm{q}_{\mathrm{e}_{2}}\right)$ is subject to a different set of errors. The first term in Eq. 2 is the rate at which heat is added to the warm water in the heater. The flow through the heater, $m_{h}$, i.s measured by a turbine flowmeter to $\pm 0.15 \%$ of the actual flow. The value of $\Delta \mathrm{T}_{\mathrm{h}}$ is measured to $\pm 0.2^{\circ} \mathrm{F}$ in about $20^{\circ} \mathrm{F}$, or to $\pm 1 \%$. Thus, the total uncertainty in $\mathrm{q}_{\mathrm{e}} 2$ from this term is $\pm 1 \%$. The second term in Eq. 2 was derived from pump efficiency data supplied by the pump manufacturer. It is a reasonable fit to the data up to $4000 \mathrm{gpm}$ and contributes an uncertainty to $\mathrm{q}_{\mathrm{e}} 2$ of $\pm 1.3 \%$. The third term in the equation represents the ambient heat loss from the piping, tanks, and other components of the warm water loop. It is less than $1 \%$ of the total heat, so the rough estimate used for $\mathrm{T}_{\mathrm{a}}$ produces an error in $\mathrm{q}_{\mathrm{e} 2}$ from this term of only $\pm 0.2 \%$. Hence, the total estimated uncertainty in $\mathrm{q}_{\mathrm{e}} 2$ is about $2.5 \%$.

It should be noted that the second term in Eq. 2, which accounts for the frictional conversion of mechanical energy to heat, carries the assumption that the flow through the pump is the same as that through the evaporator. In fact, this is not the case because of a small bypass flow around the pump through a water filter (not shown in Fig. 2). The effect of this additional pump flow, which was neglected in the calculations of $q_{e}$, was found by direct measurement of the water temperature increase across the pump to amount to about $200,000 \mathrm{Btu} / \mathrm{hr}$ at $3200 \mathrm{gpm}$ (evaporator flow), or about $6 \%$ of $\mathrm{q}_{\mathrm{e} 2}$. Spot checks of several runs comparing $\mathrm{q}_{\mathrm{e} 2}$ corrected for this additional heat input with $\mathrm{q}_{\mathrm{el}}$ showed agreement in all cases to within $\pm 20,000 \mathrm{Btu} / \mathrm{hr}$, well within the estimated combined uncertainties of $\mathrm{q}_{\mathrm{el}}$ and $q_{e 2}$

The third method for computing the heat duty is based on the rate at which energy is gained by the ammonia passing through the evaporator. . As indicated above, $q_{e}^{\prime}$ is the sum of latent and sensible heat contributions. Although measured by a turbine meter that is accurately calibrated $( \pm 0.5 \%)$, the ammonia flow $\left(m_{\ell}^{\prime}\right)$ is rather unsteady for the following reason. The flow is controlled by a valve operated by a $\Delta \mathrm{p}$ cell that indicates the 1iquid level in the flooded-bundle evaporator. The liquid level reading, which is indicated on the data printout (Fig. 3), is measured relative to a reference 
level that is 20 in. below the tops of the tubes in the top row of the bundle. The $\Delta \mathrm{p}$ cell signal is very "noisy" because the liquid ammonia in the evaporator is in violent motion, causing the liquid surface to splash around. In addition, the whole exchanger shakes on its stand, so the $\Delta p$ cell is subjected to accelerations. Hence, although the instruments hold the liquid in the evaporator at an almost constant level, the ammonia flow varies widely by a factor of 4 or 5 between the maximum and minimum. Attempts to improve this did not result in a steady flow. Manual control of the flow valve steadied the flowmeter reading, but not at the correct value, since invari$a b 1 y$ the level gradually increased or decreased with time. For these reasons no quantitative use can be made of the values of $q_{e}^{\prime}$ other than as a rough check on $q_{e l}$ and $q_{e 2}$. No calculations of $U_{0}$ based on $q_{e}^{\prime}$ were made.

\section{TEST RESULTS ${ }^{1}$}

\subsection{INITIAL RUNS: DEACTIVATION AND REACTIVATION OF THE HIGH FLUX SURFACE}

The first performance tests of the Union Carbide flooded-bundle evaporator were conducted in November-December 1977. Measurements were taken at design operating conditions, that is, at an ammonia-side temperature of $72^{\circ} \mathrm{F}$ and a warm water flow rate of $3200 \mathrm{gpm}$. A total of eight runs were made over a range of inlet warm water temperatures of $75-83^{\circ} \mathrm{F}$ and a range of heat duties of $1.4-5$ million $B t u / h r$. The results for $U_{O}$, reported at the Fifth Ocean Thermal Energy Conversion Conference, ${ }^{2}$ were in the range of $760-795 \mathrm{Btu} / \mathrm{hr} \cdot \mathrm{ft}^{2} \cdot{ }^{\circ} \mathrm{F}$.

Test runs were also made at water flow rates of $2400 \mathrm{gpm}$ ( 3 runs) and $4000 \mathrm{gpm}$ ( 4 runs), but no conclusions could be drawn from such a small amount of data. Subsequent efforts during March-May 1978 were devoted to obtaining additional data over this range of flow rates and to examining the reproducibility of the test results. These runs were made intermittently over a period of several weeks because of necessary shutdowns for equipment repairs, modifications to the piping, installation of additional instrumentation, and experiments to evaluate measurement errors. It was found that measurements made during this period were reproducible during a given day, but that from day to day and week to week variations were well beyond the errors of measurement. Repeating a measurement made days before might yield either a higher or lower value of $U_{0}$, but over time the values drifted lower, 
eventually reaching $600-625 \mathrm{Btu} / \mathrm{hr} \cdot \mathrm{ft}^{2} \cdot{ }^{\circ} \mathrm{F}$ at design operating conditions.

Union Carbide personnel were consulted regarding possible causes of this gradual decrease in $U_{0}$. Fouling of the water-side surfaces was ruled out because of the erratic, up-and-down development of the added heat transfer resistance. Contamination of the High Flux surface by water occlusion or by an oil film was rejected for the same reason and also because of the very small concentrations of these substances in the ammonia. (The amount of water present in the ammonia at that time was 500-600 ppm.). It was tentatively concluded that the most likely cause was deactivation of nucleate boiling sites on the High Flux surface by the flooding of surface pores with liquid ammonia. In order to test the validity of this explanation, the Union Carbide personnel suggested that heating the water to above $100^{\circ} \mathrm{F}$ with the ammonia side of the exchanger under vacuum would cause any liquid ammonia contained within the pores to be boiled out, thus restoring the surface to its original state. Accordingly, warm water at $120^{\circ} \mathrm{F}$ was circulated through the evaporator for about 3 hours with pressure on the ammonia side of less than 100 microns. Liquid ammonia was then fed to the bottom of the evaporator with the result that boiling began immediately upon contact with the tubes. The lowest tubes in the bundle were contacted when the water was at $120^{\circ} \mathrm{F}$. However, the pressure in the evaporator was so high that the liquid level could be raised only as the water cooled; by the time the boiling ammonia reached the top row of tubes, the recirculating water temperature had dropped to $80^{\circ} \mathrm{F}$. Eleven sets of data were then taken during a period of continuous boiling before the facility was shut down for the night. The nine $U_{0}$ values at a water flow rate of $3200 \mathrm{gpm}$ averaged $827 \mathrm{Btu} / \mathrm{hr} \cdot \mathrm{ft}^{2} \cdot{ }^{\circ} \mathrm{F}$. The one value for a water flow rate of $4000 \mathrm{gpm}$ was $943 \mathrm{Btu} / \mathrm{hr} \cdot \mathrm{ft}^{2} \cdot{ }^{\circ} \mathrm{F}$, and the one for $2400 \mathrm{gpm}$ was $720 \mathrm{Btu} / \mathrm{hr} \cdot \mathrm{ft}^{2} \cdot{ }^{\circ} \mathrm{F}$.

The next day the water was heated to $85^{\circ} \mathrm{F}$ and the water recirculation was started before 1iquid ammonia was pumped into the evaporator. Immediately after steady operation was reached at $3200 \mathrm{gpm}$, data taken gave a $U_{0}$ value of $891 \mathrm{Btu} / \mathrm{hr} \cdot \mathrm{ft}^{2} \cdot{ }^{\circ} \mathrm{F}$. Shortly after these data were taken the chiller tripped off, so the steam supply had to be shut off. During the ensuing one-hour period while the refrigeration machine was restarted and the facility brought back into operation, a pool of liquid ammonia, not boiling, remained in the evaporator in contact with the entire tube surface area. 
When operation was resumed at the end of the hour of shutdown and data were taken, it was.found that $\mathrm{U}_{\mathrm{O}}$ had dropped to $760 \mathrm{Btu} / \mathrm{hr} \cdot \mathrm{ft}^{2}{ }^{\circ} \mathrm{F}$. As operation of the evaporator continued, $\mathrm{U}_{\mathrm{o}}$ decreased gradually, reaching $752 \mathrm{Btu} / \mathrm{hr}$. $\mathrm{ft}^{2} \cdot{ }^{\circ} \mathrm{F}$ an hour after resumption of boiling.

Thus, it appears that contact with nonboiling liquid ammonia (such as would occur during shutdown periods when the warm water flow is stopped) causes a substantial and rapid deactivation of the Linde High Flux surface. To further test this hypothesis, the steam was again shut off for an hour with nonboiling ammonia left in contact with the surfaces of the evaporator tubes. After the shutdown the facility was put into operation again; data taken as soon as steady operation was attained yielded a $U_{0}$ value of $691 \mathrm{Btu} /$ $\mathrm{hr} \cdot \mathrm{ft} \mathrm{f}^{2}{ }^{\circ} \mathrm{F}$, a further decline. Rough extrapolation of these three data points suggested that $U_{0}$ might fall to $600 \mathrm{Btu} / \mathrm{hr} \cdot \mathrm{ft}^{2}{ }^{\circ} \mathrm{F}$ or below if the High Flux surface were to remain in contact with nonboiling ammonia for a sufficiently long time.

Because this characteristic of the High Flux surface was not known about until this stage of testing, the state of the ammonia-side surface during the earlier runs is uncertain. Therefore it must be concluded that all data taken on the flooded-bundle evaporator up to this point are of only qualitative use.

\subsection{EXTENDED RUN TO DETERMINE THE LONG-TERM PERFORMANCE OF THE FLOODED-BUNDLE EVAPORATOR}

In further discussions with Union Carbide personnel it was learned that transient effects of the type observed with the test evaporator do occur at times during start-up of evaporators with High Flux tubes. Based on their experience, they suggested that a run of at least 72 hours of continuous operation at design conditions be made to reactivate the tube surface from its state after a lengthy shutdown to its long-term steady operating state. Accordingly, an extended test run with the flooded-bundle evaporator was undertaken from May 22-26, 1978.

To deactivate the surface, the evaporatior was allowed to stand full of liquid ammonia for a total of 40 hours prior to the extended run. It was also kept full of liquid ammonia during the period from start-up to operation at design conditions (3200 gpm water flow rate, $80^{\circ} \mathrm{F}$ inlet water 
temperature, $3.2 \mathrm{million} \mathrm{Btu} / \mathrm{hr}$ heat duty). These conditions were maintained for the first three days of operation, during which only the ammonia temperature was allowed to vary to compensate for the changing value of $U_{0}$. The results of this rum are discussed in Sec. 6.2.1.

At the conclusion of this extended run at design operating conditions, a series of runs at different water flow rates was made. The inlet water temperature was left at $80^{\circ} \mathrm{F}$ and the heat duty was kept at 3.2 million $\mathrm{Btu} / \mathrm{hr}$ for this series of tests. These tests provided data for a determination of the water-side and the ammonia-side heat transfer coefficients. The results are described in Sec. 6.2.2.

On May 25 at 1100 hours, the water flow rate was adjusted back to the design value of $3200 \mathrm{gpm}$. The heat duty and inlet water temperature remained unchanged. At 1500 hours a series of step increases in the heat duty was begun to determine the dependence of $U_{0}$ on this parameter.

Finally, on May 26 at 1200 hours a series of tests was begun to investigate the effect of the temperature of the liquid ammonia feed to the evaporator on the value of $U_{0}$.

\subsubsection{Steady-State Value of. $U_{0}$ for Design Operating Conditions}

The data for the entire 5-day run are shown in Fig. 4. The first set of data, taken on May 22 at 0120 hours, gave a value of $606 \mathrm{Btu} / \mathrm{hr} \cdot \mathrm{ft}^{2} \cdot{ }^{\circ} \mathrm{F}$ for the overall heat transfer coefficient, $U_{0} \cdot U_{0}$ increased slowly with time and reached a steady value after about 100 hours of operation. The values of $U_{0}$ at 1400 hours on May 25, at 0700 hours on May 26, and at 2000 hours on May 26 are all $785 \mathrm{Btu} / \mathrm{hr} \cdot \mathrm{ft}^{2} \cdot{ }^{\circ} \mathrm{F}$; this is the ultimate steady value of $U_{0}$ for operation at design conditions.

\subsubsection{Individual Heat Transfer Coefficients}

Individual ammonia-side and water-side heat transfer coefficients can be determined by the standard Wilson procedure. This procedure makes use of the relationship between $U_{0}$ and the individual coefficients that expresses the total heat transfer resistance as the sum of its separate components. 


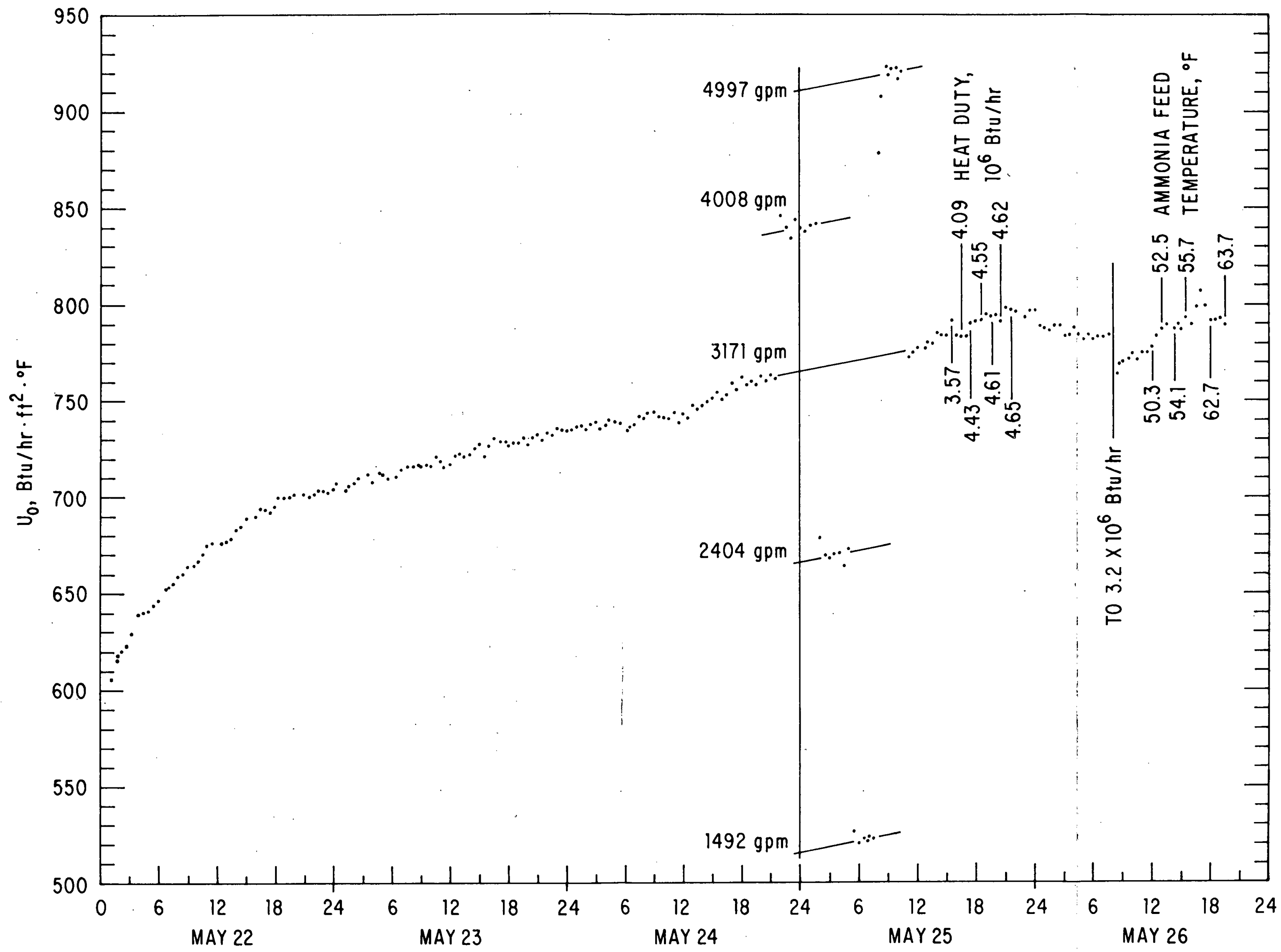

Fig. 4。 Extended Run Results 
For circular-tube heat exchangers this relationship is:

$$
\frac{1}{U_{o}}=\frac{A_{o}}{h_{i} A_{i}}+\frac{1}{h_{o}}+\frac{\Delta r A_{o}}{k A_{1 m}}+\frac{1}{h_{f o}}+\frac{A_{0}}{h_{f i} A_{i}}
$$

For circular tubes the water-side coefficient, $h_{i}$, is generally found to be proportional to the 0.8 power of the water flow rate, so $U_{0}^{-1}$ is linearly proportional to $\mathrm{w}^{-0.8}$. Thue, if a series of runs are made over a range of water flow rates under conditions where $h_{0}$ is constant, a plot of the values of $\mathrm{U}_{\mathrm{O}}^{-1}$ versus $\mathrm{w}^{-0.8}$ should fall on a straight line. Extrapolation of the line to the intercept at $\mathrm{w}_{\mathrm{e}}^{-0.8}=0$ will yield a value of $\mathrm{U}_{\mathrm{o}}^{-1}$ that is equal to the sum of the last four terms on the right side of Eq. 7 . The value of the ammonia-side coefficient, $h_{0}$, can then be determined by subtracting the values of the tube wall and fouling resistances, if they are known. Finally, the values of the water-side coefficient, $h_{i}$, can be obtained for each value of $w_{e}$.

Clearly, the use of this procedure for determining $h_{o}$ and $h_{i}\left(w_{e}\right)$ requires that the data on $\mathrm{U}_{\mathrm{o}}\left(\mathrm{w}_{\mathrm{e}}\right)$ be obtained under conditions where $\mathrm{h}_{\mathrm{O}}$ is constant and the fouling coefficients, $h_{f_{0}}$ and $h_{f i}$, are known. In order to ensure that $h_{0}$ remained the same during the runs at different water velocities, the evaporator heat duty, $q_{e}$, was held constant at the nominal design value of $3.2 \mathrm{million} B t u / \mathrm{hr}$. Although the inlet warm water temperature was held constant, the ammonia-side temperature had to vary slightly from run to run in order to accommodate the different values of $\mathrm{U}_{\mathrm{O}}$. Consequently, the profiles of the local difference between the water and ammonia temperature alung the length of the tubes were not the same for the different flow rates. However, since the nucleate boiling coefficient for the High Flux surface is only very weakly dependent on the water-ammonia temperature difference, ${ }^{3}$ the value of $h_{0}$ can safely be regarded as constant during the runs for the Wilson determination of $h_{0}$.

The requirement that the fouling resistances be known is a somewhat less certain matter, particularly in the case of the water-side fouling coefficient, $h_{f i}$. Because of precautions taken to maintain the cleanliness of the test facility's ammonia system (see Sec. 4), it is unlikely that foreign materials from this system could foul the High Flux surface. As far as water-side fouling is concerned, the water system has been maintained under a nitrogen blanket since the initial filling. The water is contin- 
uously filtered during operation by a high-capacity filter located in a bypass line around the warm water pump. The extreme cleanliness of the system and the effectiveness of the corrosion inhibitor in scavenging oxygen and in preventing the deposit of hard calcium lead us to expect that the magnitude of the water-side fouling resistance is essentially zero. Thus it can be assumed that the last two terms in Eq. 7 are small enough to be neglected in determining $h_{0}$ and $h_{i}$ by the Wilson procedure.

On May 24 and 25 of the extended run readings of $U_{0}$ were taken at several different water flow rates $(1500-5000 \mathrm{gpm})$ at a heat duty of 3.2 miliion $\mathrm{Btu} / \mathrm{hr}$. During the elapsed time of the readings the reactivation of the High Flux surface was continuing, as shown by the base line in Fig. 4 joining the $U_{0}$ values at 2000 hours on May 24 with those at 1200 hours on May 25. Because the values of $U_{0}$ were increasing during the period of data taking, it was necessary to extrapolate the data at the different flow rates to a common reference time. To do this, lines parallel to the base line were

Table 3. Values of $U_{0}$ as a Function of Flow Rate

\begin{tabular}{cc}
\hline $\begin{array}{c}\mathrm{w}_{\mathrm{e}} \\
(\mathrm{gpm})\end{array}$ & $\begin{array}{c}\mathrm{U}_{\mathrm{o}} \\
\left(\mathrm{Btu} / \mathrm{hr} \cdot \mathrm{ft}^{2} \cdot{ }^{\circ} \mathrm{F}\right)\end{array}$ \\
\hline 1492 & 51.4 \\
2404 & 665 \\
3171 & 764 \\
4008 & 840 \\
4997 & 909 \\
\hline
\end{tabular}
drawn through the data obtained for $U_{0}$ at each of the other four flow rates, and the values of $U_{0}$ that would have been obtained for the High Flux surface condition at 2400 hours on May 24 were determined. These values are given in Table 3 .

$$
\text { A large-size plot of } \mathrm{u}_{0}^{-1}
$$
versus $w_{e}-0.8$ was made to obtain the value of $U_{o}{ }^{-1}=0.000559 \mathrm{hr} \cdot \mathrm{ft}^{2}$ $:^{\circ} \mathrm{F} / \mathrm{Btu}$ at the intercept $\mathrm{w}^{-0.8}$ =0. A smaller-size graph is shown

in Fig. 5. The wall resistance term on the right side of Eq. 7 was calculated using the following data for the flooded-bundle evaporator:

$$
\begin{aligned}
& r_{0}=0.06250 \mathrm{ft} \\
& r_{i}=0.05958 \mathrm{ft} \\
& k=9.5 \mathrm{Btu} / \mathrm{hr} \cdot \mathrm{ft} \cdot{ }^{\circ} \mathrm{F}
\end{aligned}
$$

From this we obtain:

$$
\frac{\Delta \mathrm{rA}}{\mathrm{kA}_{1 \mathrm{~m}}}=0.000314 \mathrm{hr} \cdot \mathrm{ft}^{2} \cdot{ }^{\circ} \mathrm{F} / \mathrm{Btu}
$$


Substitution of this into Eq. 7 gives a value of $h_{0}$ of $4100 \mathrm{Btu} / \mathrm{hr} \cdot \mathrm{ft}{ }^{2} \cdot{ }^{\circ} \mathrm{F}$; However, this value is for a surface condition that is slightly deactivated $\left(\mathrm{U}_{\mathrm{o}}=764 \mathrm{Btu} / \mathrm{hr} \cdot \mathrm{ft}^{2} \cdot{ }^{\circ} \mathrm{F}\right)$; hence, a correction must be made to obtain the ultimate steady-state value of $h_{0}$. This can be done by writing Eq. 7 for 2400 hours on May 24 (when $\mathrm{U}_{\mathrm{O}}=764 \mathrm{Btu} / \mathrm{hr} \cdot \mathrm{ft}^{2}{ }^{\circ} \mathrm{F}$ ) and for 1400 hours on May 25 (when $U_{0}$ has reached its ultimate value of $785 \mathrm{Btu} / \mathrm{hr} \cdot \mathrm{ft}^{2} \cdot{ }^{\circ} \mathrm{F}$ ) and subtracting one from the other. This gives:

$$
\frac{1}{764}-\frac{1}{785}=\frac{1}{4100}-\frac{1}{h_{0}}
$$

Hence :

$$
\mathrm{h}_{\mathrm{o}}=4800 \mathrm{Btu} / \mathrm{hr} \cdot \mathrm{ft}^{2} \cdot{ }^{\circ} \mathrm{F}
$$

This can be compared with the value of $5500 \mathrm{Btu} / \mathrm{hr} \cdot \mathrm{ft}^{2} \cdot{ }^{\circ} \mathrm{F}$ measured for clean High Flux tubes in a bench-scale heat exchanger test at Union Carbide Corporation. The small difference between these two values may be due to the presence of fouling on the tube sur-

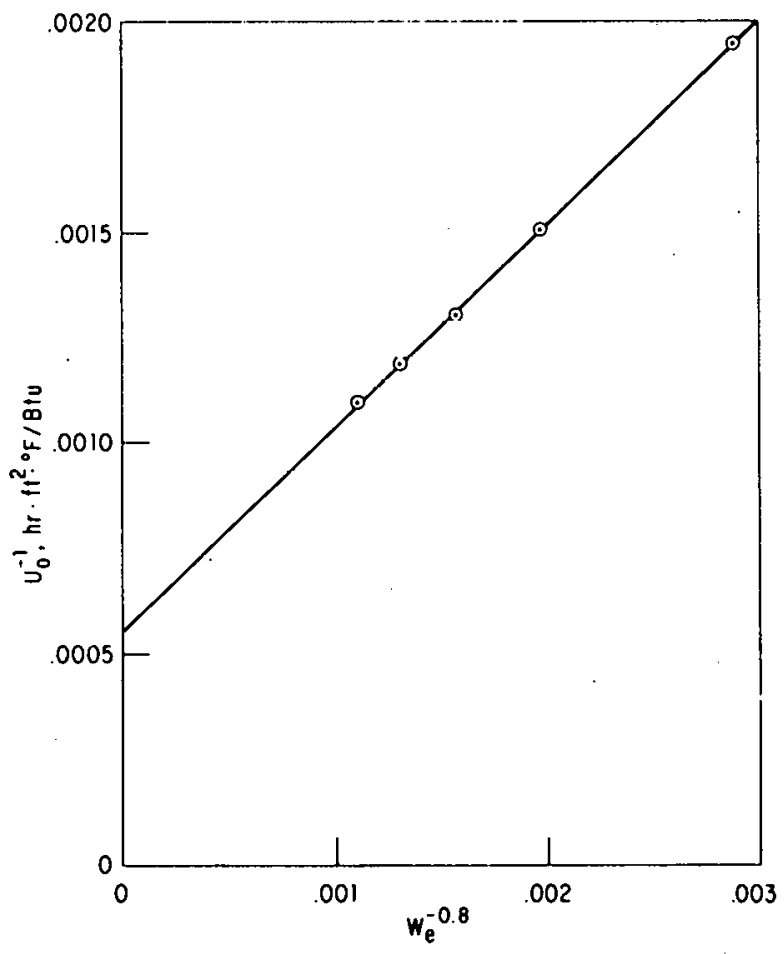

Fig. 5. Wilson Plot faces in the exchanger tested at Argonne; a fouling film with a resistance of only $0.000027 \mathrm{hr} \cdot \mathrm{ft}^{2} \cdot{ }^{\circ} \mathrm{F} /$ Btu, which would account for the difference between the two values of $h_{O}$, could have formed on the tube walls from residues left during cleaning and hydrotesting.

From this and the values for $\mathrm{U}_{\mathrm{o}}$ in Table 3 we can calculate $\mathrm{h}_{\mathrm{i}}$ for each flow rate. The results are shown in Table 4 and plotted in Fig. 6. It can be seen that the values of $h_{i}$ plotted in Fig. 6 are correlated well by the usually observed empirical form, $h_{i} \propto w_{e}{ }^{0.8}$; the equation for the line drawn through the data is $h_{i}=2.18 w_{e} e^{0.8}$. However, 
Table 4. Dependence of $h_{i}$ on Flow Rate

\begin{tabular}{lc}
\hline $\begin{array}{c}\mathrm{w}_{e} \\
(\mathrm{gpm})\end{array}$ & $\begin{array}{c}\mathrm{h}_{1} \\
\left(\mathrm{Btu} / \mathrm{hr} \cdot \mathrm{ft}^{2} \cdot{ }^{\circ} \mathrm{F}\right)\end{array}$ \\
\hline 1492 & 756 \\
2404 & 1110 \\
3171 & 1400 \\
4008 & 1660 \\
4997 & 1940 \\
\hline
\end{tabular}

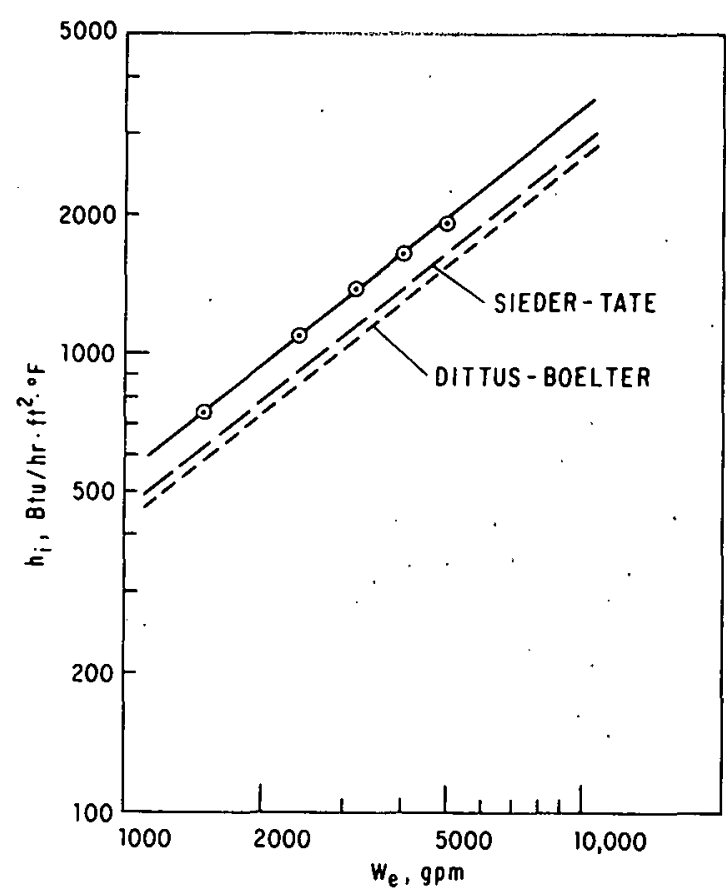

Fig. 6. Variation of Water-Side Coefficient with Water Flow Rate the values 1 ie some $20-30 \%$ above those calculated from the general1y accepted Sieder-Tate and DittusBoelter equations. There is no apparent explanation for this discrepancy.

\subsubsection{Effect of Heat Duty on $U_{0}$} The data plotted in Fig. 4 starting at 1500 hours on May 25 show the variation of $U_{0}$ as the heat duty was increased from 3.31 to 4.64 million $\mathrm{Btu} / \mathrm{hr}$. The coefficient went up from 785 to $796 \mathrm{Btu} / \mathrm{hr} \cdot \mathrm{ft}^{2} \cdot{ }^{\circ} \mathrm{F}$ and then decreased back to its original value in the next 8 hours (during which the heat duty was held at 4.6 million Btu/hr). Then at 0800 hours on May 26 the heat duty was suddenly reduced from 4.61 to 3.18 million $B t u / h r$. The value of $U_{0}$ dropped suddenly from 784 to $763 \mathrm{Btu} / \mathrm{hr} \cdot \mathrm{ft}^{2} \cdot{ }^{\circ} \mathrm{F}$. However, during the next four hours of operation at this heat duty $U_{0}$ recovered to almost the original value.

\subsubsection{Effect of Temperature of the Liquid Ammonia Feed to the Evaporator}

At 1200 hours on May 26 (see Fig. 4) a series of step changes in the temperature of the ammonia liquid feed to the evaporator was started. During this run, while the ammonia feed temperature increased from $48^{\circ}$ to $64^{\circ} \mathrm{F}$, the value of $\mathrm{U}_{\mathrm{O}}$ stayed generally in the range of $785-795 \mathrm{Btu} / \mathrm{hr} \cdot \mathrm{ft}^{2}{ }^{\circ} \mathrm{F}$. Consequently, no significant effect of ammonia liquid feed temperature on $U_{0}$ was observed. 
Table 5. Water-Side Pressure Drop as a Function of Flow Rate

\begin{tabular}{cc}
$\begin{array}{c}\text { Flow rate } \\
\text { (gpm) }\end{array}$ & $\begin{array}{c}\text { Measured pressure drop } \\
\text { (psi) }\end{array}$ \\
\hline 1492 & 0.57 \\
2404 & 1.55 \\
3171 & $2.72^{\mathrm{a}}$ \\
4008 & 4.32 \\
4997 & 6.61 \\
\hline
\end{tabular}

$a_{\text {The value of the pressure drop }}$ predicted from the design procedure for $3200 \mathrm{gpm}$ is $2.75 \mathrm{psi}$.

\subsubsection{Water-Side Pressure Drop}

Data on the water-side pressure drop were taken during the runs on May 24-25 when the water flow rate was being varied at constant evaporator heat duty and water inlet temperature. Table 5 is a summary of these data.

\subsubsection{Vapor Quality}

As mentioned previously, the vapor flowing from the evaporator may contain entrained droplets of liquid

ammonia. The quality of this stream is defined as the mass flow rate of vapor divided by the sum of the mass flow rates of vapor and liquid droplets.

As described in Sec. 3.1, a turbine flowmeter was installed in the liquid line from the demister to measure the flow rate of liquid removed from the vapor. However, it was found that the flow rate was too small to produce a measurable value. This indicates that the quality of the vapor was very high. Observations with the differential-pressure-cell system (see Sec. 3.1) likewise showed no liquid flow from the demister during any of the numerous runs for which measurements were made.

The temperature and pressure of the ammonia vapor from the floodedbundle evaporator were measured at the evaporator discharge nozzle and also in the vapor line to the condenser after the pressure-reducing valve. The measured amount of superheat of the vapor after the expansion was equal to that expected if the quality of the vapor flowing to the valve were $100 \%$.

Finally, visual observations of the vapor in the evaporator were made with a bright, well-collimated beam of light directed into the vapor space just above the boiling liquid. The inside of the shell appeared to be filled with a very light fog. Larger droplets leaving the liquid surface fell back into the liquid after traveling one or two inches. From all of the foregoing, we conclude that the disengaging space is adequate in size and the vapor velocity is. low enough that the quality of vapor leaving the evaporator is essentially $100 \%$. 


\section{SUMMARY AND CONCLUSIONS}

An investigation has been made of the performance of the Union Carbide/Linde flooded-bundle evaporator under nominal design operating conditions -- specifically, a heat duty of $3.2 \mathrm{million} \mathrm{Btu} / \mathrm{hr}$, an inlet water temperature of $80^{\circ} \mathrm{F}$, and a water flow rate of $3200 \mathrm{gpm}$. Under these conditions the value of the overall heat transfer coefficient $\left(U_{0}\right)$ for the evaporator is $785 \mathrm{Btu} / \mathrm{hr} \cdot \mathrm{ft}^{2} \cdot{ }^{\circ} \mathrm{F}$, and the ammonia-side and water-side heat transfer coefficients are 4800 and $1400 \mathrm{Btu} / \mathrm{hr} \cdot \mathrm{ft}^{2} \cdot{ }^{\circ} \mathrm{F}$, respectively. The water-side pressure drop is 2.7 psi.

The tests conducted on the Linde flooded-bundle evaporator show that the heat transfer performance depends in part on the immediate past history of operation of the exchanger. In particular, contact between the liquid ammonia and the High Flux tube surface under nonboiling conditions appears to deactivate nucleate boiling sites, thus reducing the heat transfer coefficient. The observed rate of deactivation is fairly rapid at first: a boiling stoppage of only one hour caused a drop in $\mathrm{U}_{0}$ from 750 to $690 \mathrm{Btu} /$ $\mathrm{hr} \cdot \mathrm{ft}^{2} \cdot{ }^{\circ} \mathrm{F}$. The rate slows to zero over a shutdown period of several hours at the end of which the value of $U_{O}$ has fallen to its ultimate minimum of some $600 \mathrm{Btu} / \mathrm{hr} \cdot \mathrm{ft}^{2} \cdot{ }^{\circ} \mathrm{F}$.

Operation of the evaporator under boiling conditions reverses this effect, but at a much slower rate. Thus, about 100 hours of continuous boiling at nominal design operating conditions are required to fully reactivate the High Flux surface to a $U_{0}$ value of $785 \mathrm{Btu} / \mathrm{hr} \cdot \mathrm{ft}^{2} \cdot{ }^{\circ} \mathrm{F}$ from an initial value of $600 \mathrm{Btu} / \mathrm{hr} \cdot \mathrm{ft}^{2} \cdot{ }^{\circ} \mathrm{F}$. For OTEC plants that are operated continuously for long periods between maintenance shutdowns this characteristic of the High Flux surface is of only minor concern. Nevertheless, it may in some instances be necessary to bring the plant or module up to full operation more quickly than reactivation of the surface by normal boiling permits. For such cases at least two courses of action can be taken to avoid unacceptable delays. First, in order to minimize the amount of deactivation that occurs, the power system should be designed to quickly empty the liquid ammonia from the evaporator to storage after a shutdown. Second, during the initial phase of restarting the power module after shutdown, the warm and cold water should be circulated through the heat exchangers with the turbine bypass valve open and with no liquid ammonia in the evaporator. This will cause 
a rapid vaporization of liquid ammonia occluded in the pores of the High Flux surface and, hence, will result in a more rapid reactivation than occurs during normal ammonia boiling. In future studies we will attempt to determine just how fast the surface reactivation can be accomplished in this manner.

With respect to other matters pertaining to performance of the flooded-bundle evaporator, it was found that the amount of liquid droplet entrainment in the vapor produced is so small as to be undetectable; this indicates that the vapor quality is $>99.9 \%$. It was also found that the evaporator. performance is stable to changes in heat duty: increasing the heat duty from 3.2 million to $4.6 \mathrm{million} \mathrm{Btu} / \mathrm{hr}$ produced no measurable change in $\mathrm{U}_{0}$.

Finally, reducing the subcooling of the liquid ammonia feed to the evaporator was found to have only a slight effect on thermal performarice. In particular, an increase in the liquid ammonia feed temperature from $48^{\circ} \mathrm{F}$ to $64^{\circ} \mathrm{F}$ results in an increase in $\mathrm{U}_{0}$ of only $10 \mathrm{Btu} / \mathrm{hr} \cdot \mathrm{ft}^{2} \cdot{ }^{\circ} \mathrm{F}$. Consequently, it is doubtful that the use of an ammonia feed preheater in the power cycle can be justified on a cost basis. 


\section{REFERENCES}

1. Hard-copy volumes of the test results are available from Dr. Norman F. Sather.

2. Sather, N.F.; et al., Performance Tests of 1 MWt OTEC Heat Exchangers, Proc. Fifth Ocean Thermal Energy Conversion Conf., Miami Beach, Fla., p. VI-1 (Feb. 1978).

3. Czikk, A.M., et al., Enhanced Performance Heat Exchangers, Proc. Fourth Annual Conf. on Ocean Thermal Energy Conversion, New Orleans, La., p. VI-71 (March 1977). 


\section{ACKNOWLEDGMENTS}

We wish to thank Jay Lorenz and Dave Yung for reviewing the calculations and the manuscript; Floyd Davis and Ron Rech of Globe Engineering Company for contributions during the design and construction of the test facility; and Ron Rech, Joe Dvorak, Jim Hrusosky, and Oscar Despe for assistance in operating the facility. We also appreciate the helpful comments and suggestions made by Hans Fricke of Union Carbide Corporation, Ken Bell of Oklahoma State University, and John Michel of Oak Ridge National Laboratory, all of whom reviewed the report prior to publication. 
Distribution for ANL/OTEC-PS-1

\section{Internal:}

F. W. Ahrens

P. Bensen

T. R. Bump

P. S. Chopra

J. M. Clinch

E. J. Croke

J. B. Darby

J. E. Draley
J. S. Horowitz

G. T. Kartsounes

A. B. Krisciunas

L. G. Lewis

J. J. Lorenz

K. S. Macal

R. G. Matlock

E. G. Pewitt
G. F. Popper

G. S. Rosenberg

N. F. Sather (200)

A. Thomas

D. T. Yung

R. S. Zeno

ANL Contract Copy

ANL Libraries (5)

TIS Files (6)

\section{External:}

DOE-TIC, for distribution per UC-64 (412)

Manager, Chicago Operations Office

Chief, Office of Patent Counse1, $\mathrm{CH}$

President, Argonne Universities Association

Energy and Environmental Systems Division Review Committee:

E. E. Angino, U. Kansas

T. G. Frangos, Madison, Wis.

J. H. Gibbons, U. Tennessee

R. E. Gordon, U. Notre Dame

W. Hynan, National Coal Association

D. E. Kash, U. Oklahoma

D. M. McAllister, U. California, Los Angeles

L. R. Pomeroy, U. Georgia

G. A. Rohlich, U. Texas at Austin

R. A. Schmidt, Electric Power Research Inst.

Components Technology Division Review Committee:

P. F. Cunniff, U. Maryland

W. E. Kessler, Commonwealth. Associates

N. J. Palladino, Pennsylvania State U.

N. C. Rasmussen, Massachusetts Inst. Technology

M. A. Schultz, Pennsylvania State U.

A. Sesonske, Purdue U.

H. Thielsch, ITT Grinnell Corp.

Y.C.L.S. Wu, U. Tennessee Space Inst.

H. Abelson, Mitre Corp., McLean, Va.

Alfa-Laval Thermal, Inc., South Deerfield, Md.

$\mathrm{J}$. Connel1

J. E. Yaffo

J. H. Anderson, Solar Sea Power, Inc.

K. J. Bell, Oklahoma State U.

A. Bergles, Iowa State U.

Carnegie-Mellon U.

J. Fetkovich

A. Lavi

R. Rothfus

A. Westerberg

F. H. Davis, Globe Engineering Co., Chicago 
Department of Energy

C. Castellano

R. Cohen

H. Coleman

S. Gronich

J. Hartman

E. H. Kinelski

L. Lewis

H. H. Marvin

D. E. Neely

K. Read (12)

W. Richards

W. G. Sherwood

E. N. Ganic, U. Illinois, Chicago

General Electric Company, Schenectady

R. Hindle

M. G. Olmsted

G. K. Hart, DSS Engineers, Inc., Fort Lauderdale

Johns Hopkins U./Applied Physics Laboratory

R. Cusick

J. Funk

J. George

J. Keirsey

R. Makofski

D. Richards

$\mathrm{J}$. Knudsen, Oregon State U.

Lockheed Missiles \& Space Co., Sunnyvale, Calif.

R. Conti

F. Naef

W. L. Owens

L. Trimble

R. A. Meyer, The OTEC Liaison, Chicago

Oak Ridge National Laboratory

R. Lyon

J. Miche1

L. Perrigo, Pacific Northwest Laboratories

Rand Corp., Santa Monica

C. Gazley

R. Pei

Rockwell International, Canoga Park

M. T. Constantine

W. R. Wagner

D. Wright

C. M. Sabin, Geoscience, Ltd., Solana Beach, Calif.

J. Sangiovani, United Technologies Research Center, East Hartford, Conn .

J. Sladky, Value Engineering, Alexandria, Va.

Solar Energy Research Inst.

F. Kreith

B. Shelpuk 
TRW Inc., Redondo Beach

J. Denton

R. Douglass

J. Kaellis

E. Snyder

A. Sprouse

Union Carbide Corp., Tonawanda, N. Y.

A. Czikk

H. Fricke

P. O'Neill

U. Massachusetts

W. Heronemus

$\mathrm{J}$. McGowan

Westinghouse Electric Corp., Philadelphia.

E. Barsness

J. Gertz

R. E. Williams III, PRC Energy Analysis Co., McLean, Va. 